特集記事ワークショップ報告

植物育種のためのオミックス・データ解析入門

小林正明 1,2$)$ ・大柳 一 $1,2,3)$ 矢野健太郎 1,2$)$ ・岩田洋佳 ${ }^{2,4)}$

1) 明治大学農学部, 神奈川県川崎市, $=214-8571$

2) JST・CREST，埼玉県川口市，干 332-0012

3) 三菱スペース・ソフトウェア株式会社つくば事業部，茨城県つくば市，＝ 305-0032

4) 東京大学大学院農学生命科学研究科, 東京都文京区, ₹ 113-8657

\title{
Introduction to large-scale omics data analysis for plant breeding
}

\author{
Masaaki Kobayashi ${ }^{1,2)}$, Hajime Ohyanagi ${ }^{1,2,3)}$, Kentaro Yano ${ }^{1,2)}$ and Hiroyoshi Iwata ${ }^{2,4)}$ \\ 1) School of Agriculture, Meiji University, Kawasaki, Kanagawa 214-8571 \\ 2) JST/CREST, Kawaguchi, Saitama 332-0012 \\ 3) Tsukuba Division, Mitsubishi Space Software Co., Ltd., Tsukuba, Ibaraki 305-0032 \\ 4) Graduate School of Agricultural and Life Sciences, The University of Tokyo, Tokyo 113-8657

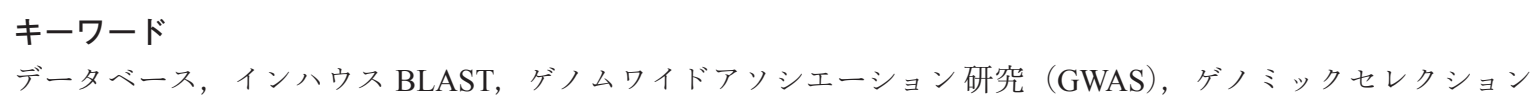

\section{ワークショップの狙い}

バイオインフォマティクスは, 高度な理論計算だけで はなく，文献検索やゲノム情報の取得，遺伝子系統樹作 成なぞ, 多くの生物学分野の研究者や大学院生にとって 身近な道具である。ささらには，わずかなコマンドライン などを修得するだけで，バイオインフォマティクスの利 活用の程度は急速に広がる。たと党ば，時間を要する煩 雑な計算機処理から解放されると同時に，自動化によっ て人為的なェラーを劇的に減らすことができる。年の上， 遺伝子機能予測や細胞内局在性予測, 代謝パスウェイ予 測など，コンピューター上で様々な予測解析が可能とな ることから，室内・圃場実験を実施する以前に実験計画 を綿密に練ることができる、研究の幅や方向性が広がる とともに，研究目標をより效率的に達成できることは明 らかである.

バイオインフォマティクスの導入とバイオインフォマ ティクスを修得した若手研究者の育成が最重要課題の 1 つであると以前から強く提言されている一方で，我が国 ではバイオインフォマティクスを積極的に活用した研究 事例が少ない。大規模な EST 解析やマイクロアレイ実 験, 高速シーケンサー解析, 質量分析を実施したものの, 効果的な解析手法を適用できて扔らず，せっかくのデー タを活用できていない場面もある。 バイオインフォマティ

2013 年 12 月 24 日受領

Correspondence: kyano@isc.meiji.ac.jp; aiwata@mail.ecc.u-tokyo.ac.jp
クス手法の導入・活用の遅れは, 我が国の生命科学にお ける国際的な研究競争力の低下を招く一因となって拈り, 早期の是正が求められる.

バイオインフォマティクスを習得するための教育・研 修基盤の整備だけではなく，ウエット，フィールド，ド ライの研究者の意識改革も必要である。文書作成や表計 算，インターネット・サーフィンをする際に，利用する ソフトウェアの多くは，マニュアルを読むことなく，基 本的な操作を直ちに実行できる、マニュアルを読まない ために，問題が生じることもほとんどない，標準となっ ているソフトウェアの多くは, ユーザーが直感的にソフ トウェアを操作できる程度までに，完成度が高められて いる. 一方, 専門性の高い情報を処理するバイオインフォ マティクスのッールやデータベースでは, 必ずしも, 使 用方法が直感的に分かるソフトゥェアばかりではない。 ソフトウェア開発者（バイオインフォマティクス研究者） が，ユーザー・フレンドリーなインターフェースの開発 に長けていない場合もある。正しく動作させ，的確な結 果を得るためには，ユーザーは，マニュアルなどを読む ベきである，同時に，バイオインフォマティクス研究者 は，第三者の意見を取り入れることによって，構築する データベースやッールの完成度を高めるべきである.

植物バイオインフォマティクス研究を推進するための 意見交換や交流の場を，より頻繁設けることが強く求 められる。これらは，ソフトウェアやッールを使う際の 使用法といった個別研究に関わる細かな質問などをする 場としてょりも，導入事例などょり汎用的な議論を活発 
に行ら場として機能することが重要である。たとえば, サーバーやワークステーションに Linux OS をインストー ルし, 独自の環境に応じたセキュリティ一設定やサービ ス設定を行い，さらに，バイオインフォマティクス関連 ッールのインストール・動作テストを実施するまでの一 連の作業には，多くの落とし穴がある，筆者らは，大会 でのグループ研究集会や講習会・シンポジウムを通して, 育種学分野に打けるバイオインフォマティクス手法の活 用と展望について多くの紹介を行ってきた。 今後, これ らの活動をさらに発展させるために, 多くの若手研究者 の積極的な参加や主催に期待したい.

本ワークショップに打いても, 育種学分野の多くの研 究者・大学院生にとって有益な内容を取り上げた，前半 と後半の 2 部構成とし, 適宜実習形式も取り込みつつ, 前半では, 小林・大柳・矢野による「話題提供 1 . 研究 室でできるバイオインフォマティクスの導入から解析ま で」を紹介し, 後半では, 岩田による「話題提供 2. 量 的形質変異をゲノム変異に結びつけるための統計解析」 を解説した，以下，それらの概要を記載する。

\section{話題提供 1. 研究室でできるバイオインフォマ ティクスの導入から解析まで}

\section{データベースとは}

データベースでは, 登録されている 1 件の記録をレコー ドとよぶ（図 1)。また，各レコードについて記載すべき 項目（フィールド）が定義されている，たとえば，「住所 録」といらデータベースに対しては, 登録されている 1 名ずつの情報が 1 つのレコードである，そして，レコー ドを記述するためのフィールドとして，氏名，年齢，住 所, 電話番号などが定義される，生命科学分野の文献情 報データベースでは, 著者, 論文タイトル, キーワード, 発表年, 雑誌名, ページ番号などのフィールドが定義さ れ，1つの論文が 1 つのレコードとなる. 配列データベー スでは, アクセッション番号, 登録者名, 生物種名, 配 列の種別（ゲノム DNA, cDNA，アミノ酸なぞ), サンプ ルの由来，配列情報などのフィールドをもつ．

データベースから目的の情報（レコード）を効率的に 抽出するためには, 各データベースのルールに従った検 索手法を用いる，たと衤ば，複数単語からなるフレーズ を用いて検索する場合，Googleでは“gene expression” のようにダブル・クォーテーションで囲らことで指定す る. このダブル・クォーテーションが入力されていない 場合, gene と expressionは独立の検索キーワードとして 認識されるため, 極めて注意を要する。遺层子配列デー タベースを用いた検索に扔いて, rice という検索キーワー ドを指定した場合，生物種イネ（Oryza sativa）だけでは なく, イネいもち病菌 (Magnaporthe oryzae), 配列の登 録者（Rice 氏）など，目的としないレコードも検索結果 に含息場合がある。目的とするレコードをデータベース

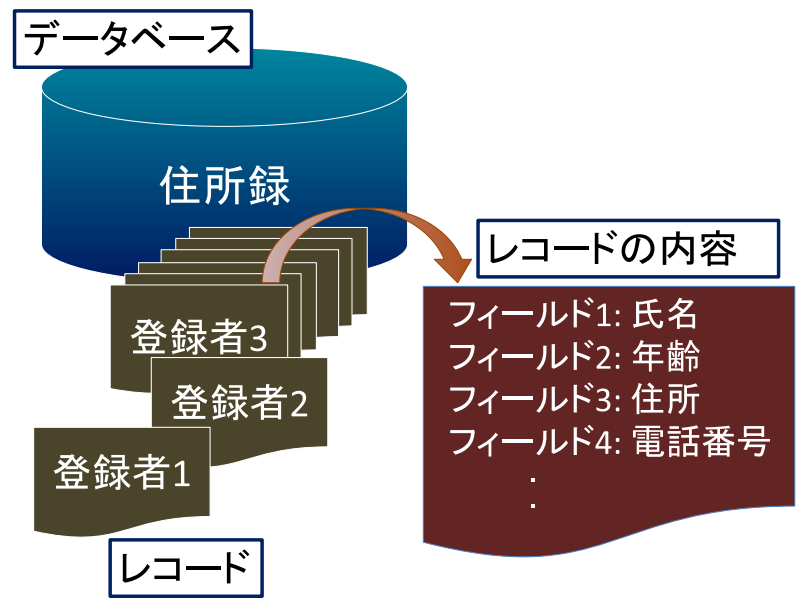

図 1. データベースとレコード，フィールドの模式図

から的確に抽出するには，フィールド指定が効果的であ る、たとえば, NCBI では, 生物種を表すフィールド [ORGN]を用い, “Oryza sativa” [ORGN]と指定することに よって, 生物種のフィールドに Oryza sativa と記載され ているレコードに絞り込むことができる. NCBI のフィー ルド指定は，へルプ・メニューを使って調べることがで きる. DDBJ/ENA/GenBank の協調体制である INSDC（国 際塩基配列データベース, International Nucleotide Sequence Database Collaboration）に扔いては, Advanced Search 機 能（検索オプション）が設けられて拉り，各フィールド の検索キーワードを指定したレコード抽出ができる.

\section{NCBI を用いた配列情報のダウンロード}

INSDC を用いて配列を検索し, 得られた配列情報をダ ウンロードすることによって, PCR プライマーの設計や 相同性検索, 遺伝子系統樹解析など様々な解析に利用で きる、 NCBI の Web サイトでは, 検索キーワードのテキ スト・ボックスの下にある “Send to” のリンクをクリッ クし, FASTA 形式などで配列情報をダウンロードでき る. ダウンロードしたファイルには，英字で始まる分か りやすい名前を付けることを铨める．検索キーワードや 検索を実行した年月日をファイル名に含めることで, ファ イル整理が極めて効率的になる。また，後で述べるイン ハウス BLASTを実行する場合, ファイル名に空白や記 号, 全角文字を含めないことが望ましい（半角のハイフ ンやアンダーバーは用いて構わない).

\section{インハウス BLAST の導入と実行}

多くの研究者にとって, 配列の相同性検索を実行する 場合, Web サイトが提供する BLAST 検索機能 (WebBLAST）を用いることが大半である. Web-BLASTを実 行するための一般的な手順として，まず，Webサイトに 抢いて事前に用意されている BLAST 配列データベース の中から検索に用いるデータベースを選択し， クエリー （問い合わせ）配列をテキスト・エリアにペーストすると 
共に，適切なプログラム名（blastnやblastpなど）を指定 する必要がある。また, 必要に応じて, 期待值（Evalue）やFilterなどのオプションを設定する。多くの Web-BLAST では，通常の BLAST の計算結果だけではな く, 配列のアライメント結果をグラフィカルに表示する など，視覚的にも解釈しやすい，Web-BLAST では，検 索実行に必要な計算機リソース（CPUやメモリーなど） をサーバーに依存するため, ユーザーは高い処理能力を もつ計算機を用意する必要がない。

Web-BLAST は簡便かつ効果的な一方で，デメリット もある。たとえば，ある遺伝子ファミリーのらち最も相 同性の高い遺伝子を探索したい場合，その遺伝子ファミ リーの BLAST 配列データベースが提供されていなけれ ば，検索そのものができない。また，膨大なクエリーを 投入した場合，検索実行の進行程度が分からないため， 結果が戻るまでブラウザーを開いた状態で待つ必要があ る.さらに，クエリ一配列に知財権などが関与する場合 には, クエリー配列情報をオンライン上で配信すること にセキュリティー上の問題がある.

インハウス BLAST は，Web-BLAST と異なり，自らの 計算機をBLAST サーバーとする。そのため，インハウ ス BLAST は, Web-BLAST と反対のメリットとデメリッ トをもつ. インハウス BLAST の大きなメリットとして, 独自の BLAST 配列データベースを自在に構築できるた め, 遺伝子配列間の相同性の程度を迅速・簡便に評価で きることが挙げられる，また，多数の検索を実行した場 合，計算処理を監視できるため，計算終了までに必要な 処理時間を予測できる。 ネットワークを介さないため, 機密情報の漏洩のリスクがない。一方で, 大規模な計算
を実施するには，処理能力の高い計算機を用意する必要 がある、また，サーバ一管理のための知識とスキルを要 すると共に，マンパワー・時間・労力が割かれる. 結果 は視覚化されないため, 解釈が煩雑である.

インハウス BLAST の導入と実行は容易である，実行 プログラムを NCBIより入手し, 自分の計算機上で, BLAST データベースを構築し, BLAST 検索を実行する (図 2). Windows, Macintosh, Linuxなどの OS に対応し た実行プログラムは，NCBI FTP サイトより入手できる. 実行の際のコマンド入力は, Windows であればコマンド プロンプト，Macintoshであればターミナルなどを用い る。また，本稿で示すコマンド例では，実際には，すべ て 1 行のコマンドである（途中で改行しない）。 まず, formatdb コマンドを用い, FASTA 形式の配列情報ファイ ルを BLAST データベースに変換する。たと党ば，塩基 配列の FASTA ファイル（seq.fasta）を使って BLAST デー タベースを構築する際には, 以下のコマンドを実行する.

formatdb -i seq. fasta $-p \quad F-\circ$ T

次にクエリー配列と相同な配列を BLAST データベー スから探索するには， blastall コマンドを用いる，たとえ ば，クエリ一配列（塩基配列）がFASTA 形式ファイル query.fasta に保存されており, 先述の FASTA形式ファイ ル seq.fasta から作成した BLAST データベースに対して, blastnプログラムによって検索する場合, 以下のコマン ドを用いる。

blastall -p blastn -i query.fasta - d seq.fasta この結果は計算機モニタ一上に出力される. 以下のよう

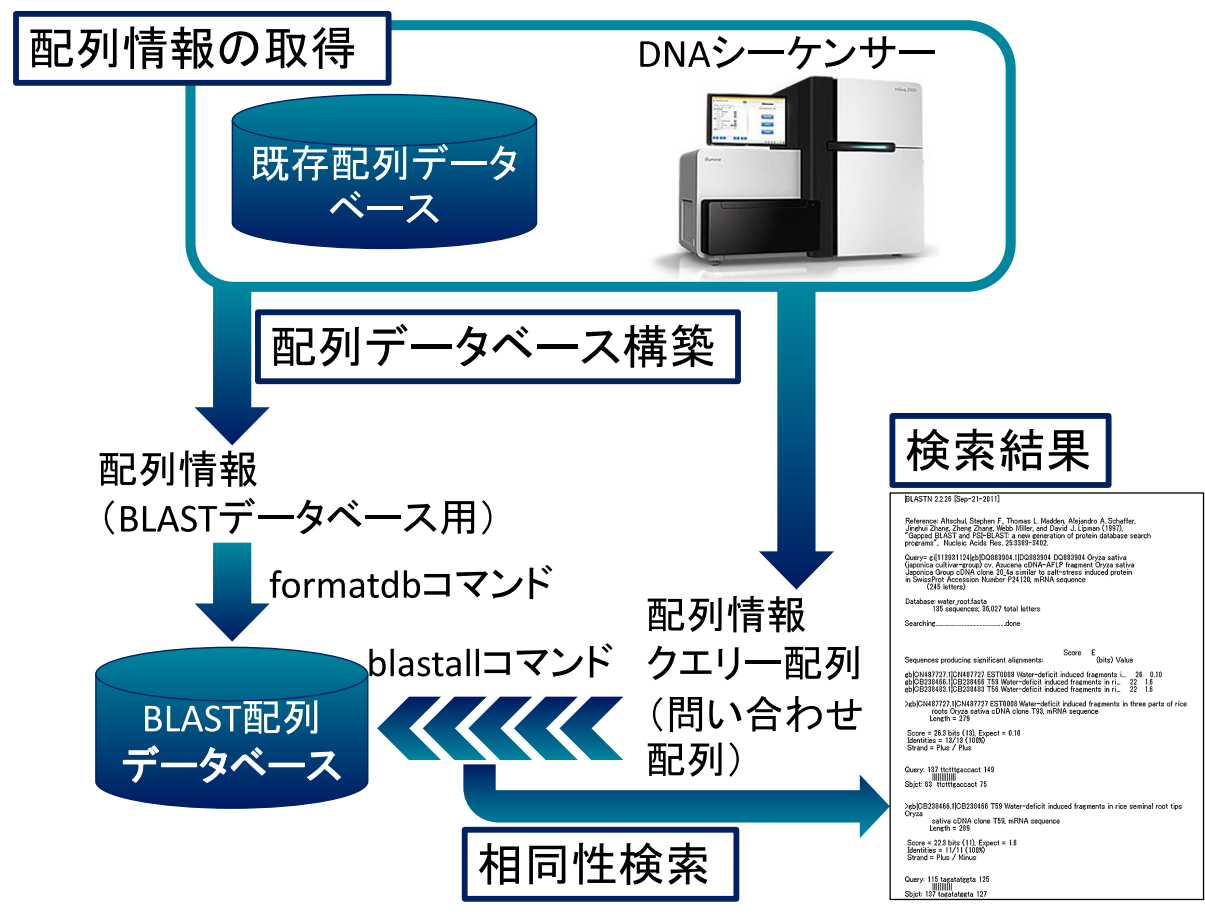

図 2.インハウス BLAST の概要図 
に出力先オプションを追加することによって，結果は計 算機モニターではなく, 新規ファイル result.out に格納さ れる.

blastall -p blastn -i query.fasta - d seq.fasta -o result.out

ワークショップでは, インハウス BLAST 以外に, Perl プログラムの実行方法なぞも解説した。 これらの基本的 なバイオインフォマティクス手法の導入については, 今 後, Web サイトや解説・ノートなどで紹介できれば幸い である.

\section{話題提供 2. 量的形質变異をゲノム变異に結びつ けるための統計解析}

近年, 高速シークエンサ等を用いて, 多数のサンプル について多数の DNA 多型を調べることが可能となって いる（Davey et al. 2011）。こうして得られるゲノム情報 を育種に活用する手法として, 表現型データとゲノムデー タ間の関係から（1）遺伝子を検出するゲノムワイドアソ シエーション研究 (genome-wide association study: GWAS)，（2）遺伝的能力を予測するゲノミックセレク ション（genomic selection: GS）などが挙げられる。ワー クショップでは, イネで収集されたデータ（Zhao et al. 2010）を例として用い，これら 2 手法を実行するのに必 要となる統計解析手法について解説を行った. 解析には, 主に統計パッケージ R（R Core Team 2013）を用いた。 な お， ワークショップで用いた資料は，http://papaya.ab.a.utokyo.ac.jp/groups/iwata からダウンロードできる.

\section{データの補完}

高速シークェンサを用いたジェノタイピング法である RAD-seq (restriction site associated DNA sequence; Baird et al. 2008) や GBS (genotyping-by-sequencing; Elshire et al. 2011）を用いると，一般に，多数のデータが久測する. また，DNAチップを用いてジェノタイピングしても，全 マーカーについて, 完全なデータが得られるわけではな い.こうして久測したデータの取り扱いかたには様々な 方法が考光られるが，最近よく用いられているのは，久 測データを何らかの方法で補完し，補完されたデータを GWAS や GS に用いるといら方法である。ワークショッ プでは, BEAGLE（Browning and Browning 2007）を用い た補完方法について解説した。

BEAGLEは Javaで書かれて和り，Windows， Mac， Linux など，様々な OS で利用できる，BEAGLEを利用 して, 連鎖の相（linkage phase）の推定や遺伝子型データ の補完ができる，前者の機能は，遺伝子型データから八 プロタイプを推定するために用いられる。たと光ば, $\mathrm{AaBbCc}$ という遺伝子型をもつサンプルが，どのような ハプロタイプをもつか（A-B-C と a-b-c の組か，A-b-C と
a-B-c の組か，等）を推定できる，後者の機能は，欠測し た遺伝子型データの補完のためだけでなく, 高密度にジェ ノタイピングされたデータを参考に, 低密度にジェノタ イピングされたデータを補完するためにも利用できる. たと光ば，代表的な品種・系統のみを高密度にジェノタ イピングして拈き，それ以外の品種・系統については低 密度なジェノタイピングを行らことでコストと労力を抑 光, 高密度データについては補完によって求める (Jannink et al. 2009, Iwata and Jannink 2010)。 ワークショップでは, 久測データを補完する目的で BEAGLEを用いた。 BEAGLE の入力ファイルを作成するための R スクリプト や，出力ファイルをまとめるための $\mathrm{R}$ スクリプトについ て紹介し, BEAGLEの実行の仕方について解説した，そ の詳細については，上述した Web 上の資料を参考にして ほしい。な拉，BEAGLEを用いて補完を行らためには， マーカー遺伝子座の染色体上での並び順が分かっている 必要がある。位置が不明なマーカーの欠測補完について は, Rutkoski et al. (2013) が参考になるであろう.

マーカー遺伝子型データは, GWAS や GS に用いられ る前に, 数值データに変換される. 二対立遺伝子のマー カーでは, 一方のホモ接合型を 1 , 他方を-1，へテロ接 合型を 0 とする方法がよく用いられる。たと光ば，ある SNP マーカーに扔いて，AA，AT，TT といら遺伝子型が 観察された場合，それぞれを，1，0，-1 に変換する。な お，2つのホモ接合型のどちらを1にするかは任意であ る。な拉, ワークショップでは, 純系のイネをデータ例 として用いたため, へテロ接合体は無く, A, T, G, C として記述されたマーカ一遺伝子型（それぞれ，遺伝子 型 $\mathrm{AA} ， \mathrm{TT} ， \mathrm{GG}, \mathrm{CC}$ 亿対応する）を1 と-1 と変換する Rスクリプトを紹介した.

\section{集団構造の解析}

GWAS や GS モデルの構築において，材料として用い る品種・系統の遺伝的背景について情報を得ておくこと が重要である. とくにGWAS では, 後述するよらに, 集 団構造を無視すると誤った結果が導かれる可能性がある. 遺伝的背景の情報として, 育成場所や栽培地域, 系譜に 関する情報等も有用だが，マーカー遺伝子型データにも， 品種・系統の遺伝的背景に関わる情報が含まれている. ワークショップでは, 主成分分析や $k$-平均法などの多変 量解析手法を用いて, 品種・系統のもつ遺伝構造を推定 する方法について紹介した。 その詳細については，Web 上の資料を参考にしてほしい。

\section{GWAS}

遺伝子や DNA マーカーは染色体上に数珠つなぎ並 んでいる，そのため，染色体上で互いに近傍にある遺伝 子やDNA マーカーは親から子に共に伝えられやすい. これが連鎖とよばれる現象である。連鎖があることによ り, 多数の品種・系統からなる集団や育種集団に拈いて 
も，互いに近傍にある遺伝子やDNA マーカーが非独立 的な状態にある場合がある。このような遺伝子座間の非 独立的な状態を連鎖不平衡 (linkage disequilibrium: LD) とよぶ. この LD の存在が, GWAS や, 後述する GS を 可能にしている.

QTL のごく近傍にあるマーカーでは, QTL の遺伝子型 とマーカー遺伝子型間の非独立性, すなわら LD が高く なり，表現型とマーカー遺伝子型間に関連（association） を生じる. GWAS は，ゲノムワイドマーカーについて表 現型とマーカー遺伝子型間の関連の強さを解析し，それ をもとにQTLの位置を推定する方法である．量的形質の GWAS では，表現型とマーカー遺伝子型間の関連を検出 するのに，線形回帰モデルがよく用いられる．今， $i$ 番目 の個体の表現型值を $y_{i}, i$ 番目の個体の $j$ 番目のマーカー スコア（数值化されたマーカー遺伝子型）を $x_{i j}$ とする と, 表現型とマーカー遺伝子型を関連づける最も単純な 回帰モデルは,

$$
y_{i}=u+b_{i} x_{i j}+e_{i}
$$

となる。表現型とマーカー遺伝子型間の関連を調べるに は，このようなモデルをデータに当てはめ，回帰係数 $b_{j}$ の有意性を検定すればよい. しかし，このモデルを実デー タに当てはめると, 回帰係数が有意 $\left(b_{j} \neq 0\right)$ なマーカー が多数検出される。これは，品種・系統のもつ集団構造 によって生じる見かけ上の関連，すなわち，偽陽性（false positive）である（Lander and Schork 1994）。このような偽 陽性を抑えるには，集団構造による影響を考慮したモ デル

$$
y_{i}=u+b_{j} x_{i j}+\sum_{k=1}^{K} v_{k} q_{i k}+e_{i}
$$

を用いる。ここで， $q_{i k}$ は $i$ 番目の品種の遺伝的背景を表 す指数で，上述した主成分分析で計算される主成分得点 や, Structure 解析（Pritchard et al. 2000）で推定される集 団への所属確率（Q值）が用いられる。このモデルを用 いてもなお，微視的な集団構造の影響により偽陽性が生 じる場合が多い。このような偽陽性を抑えるには，微視 的な集団構造による影響も考慮したモデル

$$
y_{i}=u+b_{j} x_{i j}+\sum_{k=1}^{K} v_{k} q_{i k}+\alpha_{i}+e_{i}
$$

がよく用いられる（Yu et al. 2006）。ここで， $\alpha_{i}$ は， $i$ 番 目の品種のもつ微働遺伝子（polygene）による相加的遺 伝効果を表して和り，全品種・系統をまとめたべクトル $\alpha=\left(\alpha_{1}, \alpha_{2}, \ldots, \alpha_{J}\right)^{\mathrm{T}}$ が多変量正規分布 $M N\left(\boldsymbol{0}, \boldsymbol{K} \sigma_{\alpha}^{2}\right)$ に従らと 仮定する. ここで， $\boldsymbol{K}$ は，品種・系統間の遺伝的関係を 表す行列であり，マーカー遺伝子型をもとに計算される （たとえば，Endelman and Jannink 2012）。なお，上述した 回帰モデルは, $j$ 番目のゲノムワイドマーカーについて 1 つずつ関連を調べる方法である。したがって，M個マ一 カーがあると， $M$ 回の回帰分析を行らことになる。これ に対し，ベイズ回帰等を用いて，複数 QTL の効果を同時
に検出することで精度を向上させようとする方法も提案 されている（たとえば, Kärkkäinen and Sillanpää 2012, Hoffman et al. 2013). ワークショップでは, GWAS に用 いられる様々な回帰モデルついて, 玄米長のデータの解 析結果を示しながら，具体的に説明した．解析のための $\mathrm{R}$ スクリプト等については，Web 上の資料を参考にして ほしい。

\section{GS のための予測モデリング}

ゲノムワイドに高密度に DNA マーカーを配置するこ とにより，いずれかのマーカーがゲノム上に散在する QTL と LDが高い状態になると考えられる。これにより， マーカー遺伝子型から QTL の状態（遺伝子型）をある程 度把握できると期待される. GS では，ゲノムワイドマー カーと QTL 間の LDを利用することにより，被選抜個体 のマーカー遺伝子型をもとに, その個体の遺伝的能力（遺 伝子型值）を予測して選抜する。

GS の具体的な手順は以下の通りである. まず，多数の 品種・系統のセット，または，選抜集団に含まれる個体 や系統のセットを参照データ（トレーニングデータとよば れる）として用い，マーカ一遺伝子型から遺伝子型值を 予測するモデルを作成して扔く，選抜を行ら際には，被 選抜個体のマーカー遺伝子型に対して，作成しておいた 予測モデルを当てはめて, 遺伝子型值を予測する。 そし て, 予測された遺伝子型值をもとに優良個体を選抜する.

GWAS も GS の予測モデル構築も，マーカー遺伝子型 と表現型間の関連をモデル化する手法であり，GWAS と GS で同様の統計モデルが用いられることも少なくない. しかし，GWASとGSでは，モデル化の目的が異なる。 GWAS では，マーカー遺伝子型と表現型間の関連から， その内部システム，すなわち，遺伝子の位置や効果を明 らかにすることを目的としている。一方，GSでは，マー カ一遺伝子型と表現型間の関連を利用して, 前者から後 者を予測することが目的である.したがって，GS ではモ デルの優劣はもっぱら予測精度に依存し, 内部システム の理解の能否は問われない（たたこ，このことは遺伝子 の位置や機能に関する情報が GS の精度向上に貢献しな いことを意味しないことに注意する)。したがって，GS の予測モデル構築では, 量的遺伝学の手法に留まらず, 機械学習法を含めた様々なモデル化手法が用いられてい る（たとえば, Heslot et al. 2012）.

GS では，ゲノムワイドマーカーをすべて用いて遺伝的 能力を予測するモデルを構築し, 構築しておいたモデル をもとにマーカー遺伝子型に基づく選抜を行う。モデル 構築の際, サンプル数に比べてパラメータ数が多いため, “large $p$, small $n ”$ とばれる問題が生じる。たとえば, 表現型值 $y_{i}$ をマーカースコア $x_{i j}$ に回帰するモデル

$$
y_{i}=u+\sum_{j=1}^{J} v_{k} b_{j} x_{i j}+e_{i}
$$

を構築するためには, 表現型とマーカー遺伝子型データ 
から，回帰係数 $u, b_{j}(j=1,2, \ldots, J)$ を推定しなければなら

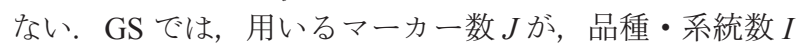
を大幅に超兄ている場合が多いため，通常の重回帰分析 では，回帰係数を推定できない，そこで，回帰係数に何 らかの制約を課すことにより, 少ない品種・系統のデー タから，多数の回帰係数を推定する．たとえば，リッジ 回帰では, 回帰係数 $b_{j}$ の 2 乗の和が大きくなることに対 して制約を課す。また, lasso では, 回帰係数 $b_{j}$ の絶対值 が大きくなることに対して制約を課す，具体的には，

$$
E_{(k)}=\sum_{i=1}^{I}\left(y_{i}-u-\sum_{j=1}^{J} b_{j} x_{i j}\right)^{2}+\lambda \sum_{j=1}^{J}\left|b_{j}\right|^{k}
$$

を最小にする $u, b_{j}$ を求める. $k=1$ のときが lasso, $k=2$ のときがリッジ回帰に相当する，右辺第 1 項は，回帰に 打残差平方和，右辺第 2 項は，回帰係数に制約を課 すためのペナルティ項である， $E_{(k)}$ を最小にするというこ とは，回帰モデルの当てはまりの良さ（右辺第 1 項）と， ペナルティの大きさ（右辺第 2 項）との間でらまくバラ ンスがとれる回帰係数を求めることを意味する。当ては まりの良さとペナルティの大きさとの間のバランスを調 整するパラメータ入は, トレーニングデータから推定さ れる場合や，交差検証（cross-validation）をもとに求めら れる場合がある。なお，リッジ回帰と lasso の中間をとる よらな手法として elastic net（「伸び縮及する網」の意） がある。そこでは,

$$
\begin{aligned}
E_{(k)}= & \sum_{i=1}^{I}\left(y_{i}-u-\sum_{j=1}^{J} b_{j} x_{i j}\right)^{2} \\
& +\lambda\left(\frac{1-\alpha}{2} \sum_{j=1}^{J} b_{j}^{2}+\alpha \sum_{j=1}^{J} \mid b_{j}\right)
\end{aligned}
$$

を最小にする $u, b_{j}$ を求める. この式から, elastic netは, $\alpha$ を 0 亿近づりとリッジ回帰に近づき， $\alpha$ を 1 亿近つ けると lasso に近づくことが分かる. 回帰係数に対する制 約の課し方の違いから，リッジ回帰はすべてのマーカー が何らかの効果をもっているよらな場合に適しており， lasso は一部のマーカーが大きな効果をもつ場合に適して いる，両者の間をとりもつ elastic netは， $\alpha$ を動かすこと により，いずれの場合にも適用できるといら特徵をもつ.

ところで, リッジ回帰は, 品種 $i$ と $j$ のーカースコ アの内積を $(i, j)$-要素にもつ行列（以下，内積行列とよ ぶ）をもとに計算することもできる（Endelman 2011）。 これは, 内積行列をカーネル行列としたカーネル回帰と して、リッジ回帰を実行することに相当する，カーネル 行列を内積行列から他の行列（たと壳ば，Gaussianカー ネル行列）に変えることにより，エピスタシス等の非相 加的遺伝効果も考慮したカーネル回帰に発展させること もできる、ワークシップでは，上述した手法について， 玄米長データを用いた解析結果を示しながら説明をした。 解析のための R スクリプト等については, Web 上の資料 を参考にしてほしい。

\section{表現型計測の効率化の重要性}

なお，GWASやGS のモデル化のためには，表現型デー タが不可欠である. GWAS による関連遺伝子検出のため にも, GS に上る高精度選抜のためにも, 多数の品種・系 統について, 計測精度の高い表現型データを収集するこ とが非常に重要である。しかし, 高速化・高効率化が進 むゲノムデータ収集に対し，表現型データの収集は，そ の高速化・高効率化が遅机ている.

表現型データの重要性から, さらには, 大量計測が可 能になったゲノムデータとの技術バランスをとるために も, 現在, 表現型データ収集の高速化・高効率化のため の様々な取り組みが進められている。 ワークショップで は，一例として，バーコードを用いた効率化について簡

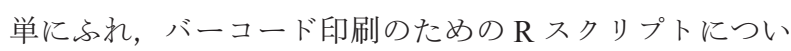
て紹介した。同スクリプトを用いることで，たとえば， 長さの情報を記述したバーコードを $1 \mathrm{~cm}$ 区切りで並べて 印刷できる。これを物差しに貼付けることで, “バーコー ド物差し”を簡単に作成できる。“バーコード物差し”を 用いることで，長さのデータを，バーコードリーダーを 用いて簡単に計測・記録できるょうになる，今後，様々 な工夫で，表現型データ収集の効率化を進めていくこと が重要である.

\section{おわりに}

今回のワークショップでは, 実際に持ち込んだノート PCで操作しながら，インターネット上の情報を抽出する 操作や BLAST の実行を行らなど, 実施も含めて開催す ることができた. Windows と Macintosh の両方の使用法 もスクリーンに映し出しながら解説すると共に, 陥りや すい落とし穴などについても紹介し，極めて実践的な内 容となった。このような充実したワークショップを開催 する上で, 大会本部の皆様には, 電源用テーブルタップ や無線 LAN アカウントの配布をしていただくなぞ，多 くのご配慮をいただいた。また，ワークショップの開始 に当たり, 大会直前に御逝去された奈良先端科学技術大 学院大学・教授・島本功先生への黙䘠を捧げることがで きた．今後も育種や植物科学の発展資するバイオイン フォマティクス関連のワークショップやグループ研究集 会などを開催する予定である。育種学会員および育種学 領域全体の研究の新たな展開のサポートとなれば幸甚で ある。

\section{引用文献}

Baird, N.A., P.D. Etter, T.S. Atwood, M.C. Currey, A.L. Shiver, Z.A. Lewis, E.U. Selker, W.A. Cresko and E.A. Johnson (2008) Rapid SNP discovery and genetic mapping using sequenced RAD markers. PLoS One 3: e3376.

Browning, S.R. and B.L. Browning (2007) Rapid and accurate 
haplotype phasing and missing-data inference for whole-genome association studies by use of localized haplotype clustering. Am. J. Hum. Genet. 81: 1084-1097.

Davey, J.W., P.A. Hohenlohe, P.D. Etter, J.Q. Boone, J.M. Catchen and M.L. Blaxter (2011) Genome-wide genetic marker discovery and genotyping using next-generation sequencing. Nat. Rev. Genet. 12: 499-510.

Elshire, R.J., J.C. Glaubitz, Q. Sun, J.A. Poland, K. Kawamoto, E.S. Buckler and S.E. Mitchell (2011) A robust, simple genotypingby-sequencing (GBS) approach for high diversity species. PLoS One 6: e19379.

Endelman, J.B. (2011) Ridge regression and other kernels for genomic selection with $\mathrm{R}$ package rrBLUP. Plant Genome 4: 250-255.

Endelman, J.B. and J.L. Jannink (2012) Shrinkage estimation of the realized relationship matrix. G3 2: 1405-1413.

Heslot, N., H.P. Yang, M.E. Sorrells and J.L. Jannink (2012) Genomic selection in plant breeding: a comparison of models. Crop Sci. 52: 146-160.

Hoffman, G.E., B.A. Logsdon and J.G. Mezey (2013) PUMA: a unified framework for penalized multiple regression analysis of GWAS data. PLoS Comput. Biol. 9: e1003101.

Iwata, H. and J.L. Jannink (2010) Marker genotype imputation in a low-marker-density panel with a high-marker-density reference panel: accuracy evaluation in barley breeding lines. Crop Sci. 50: 1269-1278.

Jannink, J.L., H. Iwata, P.R. Bhat, S. Chao, P. Wenzl and G.J. Muehlbauer (2009) Marker imputation in barley association studies. Plant Genome 2: 11.

Kärkkäinen, H.P. and M.J. Sillanpää (2012) Robustness of Bayesian multilocus association models to cryptic relatedness. Ann. Hum. Genet. 76: 510-523.

Lander E.S. and N.J. Schork (1994) Genetic dissection of complex traits. Science 265: 2037-2048.

Pritchard, J.K., M. Stephens and P. Donnelly (2000) Inference of population structure using multilocus genotype data. Genetics 155: 945-959.

Rutkoski, J.E., J. Poland, J.L. Jannink and M.E. Sorrells (2013) Imputation of unordered markers and the impact on genomic selection accuracy. G3 3: 427-439.

Zhao, K., M. Wright, J. Kimball, G. Eizenga, A. McClung, M. Kovach, W. Tyagi, M.L. Ali, C.W. Tung, A. Reynolds et al. (2010) Genomic diversity and introgression in O. sativa reveal the impact of domestication and breeding on the rice genome. PLoS One 5: e10780.

\section{当日 演題}

\section{話題提供}

1. 研究室でできるバイオインフォマティクスの導入から解析まで 矢野健太郎 1,2 ・ 小林正明 1,2 ・大柳 一 1,2,3（1. 明治大学・農学部, 2. JST・CREST, 3. 三菱スペース・ソフトウエ ア)

2. 量的形質変異をゲノム变異に結びつけるための統計解析 岩田洋佳 (東大・院農学生命科学) 